\title{
Cultivation Mode Reform for Entrepreneurship Talents in Financial Universities from Bricolage Ability Training
}

\author{
Jianming Zhou ${ }^{1}$, Nan Jiang ${ }^{2}$, Jiansheng Chen ${ }^{2, *}$ \\ ${ }^{1}$ School of Business Administration, Guangdong University of Finance \& Economics, Guangzhou, China \\ ${ }^{2}$ School of MBA, Guangdong University of Finance \& Economics, Guangzhou, China \\ ${ }^{*}$ Corresponding author. Email: chencanson@qq.com
}

\begin{abstract}
This study used 318 undergraduates and postgraduates from a financial application-oriented university as an empirical research sample to investigate the entrepreneurial resources bricolage ability of college students, so as to help relevant higher education managers to improve their entrepreneurial talents cultivation in financial universities. Results show that: (1) The entrepreneurial resources bricolage ability of financial college students is generally positive; (2) There are significant differences in the overall resources bricolage ability of students in different genders, males students will have stronger overall resources bricolage ability, especially better bricolage ability with resources recombination for new purposes; (3) There are significant differences in the training of overall resources bricolage ability between graduate students and graduate students. Graduate students are stronger at bricolage ability with resources recombination for new purposes and resources at hand, while undergraduate students are stronger at bricolage ability with resources making do. Finally, reform proposals were provided for the cultivation mode of entrepreneurial talents.
\end{abstract}

Keywords: Bricolage ability, Financial universities, Entrepreneurial talents, Reform of cultivation mode.

\section{INTRODUCTION}

At present, innovation and entrepreneurship education has become an important link in the cultivation of high-quality talents in universities, and many universities have established corresponding entrepreneurship education colleges to undertake this function. However, most of the school's training of entrepreneurial talents still provides traditional business courses in the form of curriculum teaching according to the traditional model, and has not carried out the reform of the corresponding talent training model in accordance with the actual entrepreneurial practice. Shepherd et al (2000) [1] pointed out that, for most entrepreneurial companies, it is often difficult for them to have the strong human and financial resources to develop new products like large companies, lacking of resources is often a dilemma they face. Zhou et al (2019) [2] pointed out that mastering resources bricolage ability is an important means for start-up SMEs to solve resource constraints and start entrepreneurship. Therefore, from the perspective of entrepreneurial resources bricolage ability training, it is an important entry point to improve the entrepreneurial quality of entrepreneurial talents in colleges and universities, especially for the cultivation of entrepreneurial talents in non-technical and financial universities (Zhou et al., 2016) [3]. Because most of the professional knowledge of financial college students is concentrated on the level of business education, lack of technical knowledge, it is difficult to develop marketcompetitive products to start a business, their advantage lies in the coordination and integration of resources to start a business.

Based on this, this article uses financial college students as the research object to understand the current situation of the cultivation of resources bricolage ability of financial college students and the problems in the training process, and provide relevant decision-making advices for relevant financial college educators to carry out entrepreneurial talent training reform.

\section{RESEARCH SAMPLE}

The research sample of this study comes from undergraduates and postgraduates of a financial application-oriented university in the Guangdong-Hong 
Kong-Macao Greater Bay Area. The questionnaires are mainly distributed by inviting students from the evening study room of the university at random. Each questionnaire is filled out anonymously, and the filling time is controlled at 5 minutes to ensure that the respondents are willing to fill in. Through one week of data collection, 350 questionnaires were distributed and 341 questionnaires were returned, with a recovery rate of $97.4 \%$. After excluding obvious logical errors and missing questionnaires, 318 valid sample data were

Table 1. Validity test result of entrepreneurial resources bricolage ability scale obtained. There are 118 male students, 200 female students; 169 undergraduate students, and 149 graduate students; in terms of majors, 47 students majoring in science, engineering and medicine, 164 students majoring in economics and management, and 107 students majoring in humanities, social sciences and philosophy; 173 college students from rural areas accounting. The selected samples basically conform to characteristics of our country's financial college students.

\begin{tabular}{|c|c|c|c|}
\hline Indexes & Standard Value & Acceptable Value & Results \\
\hline CFI & $\geq 0.90$ & $\geq 0.80$ & 0.947 \\
\hline GFI & $\geq 0.90$ & $\geq 0.80$ & 0.933 \\
\hline RMR & $\leq 0.05$ & $\leq 0.08$ & 0.033 \\
\hline RMSEA & $\leq 0.08$ & $\leq 0.10$ & 0.086 \\
\hline X2/df & $1.00 \sim 3.00$ & $3.00 \sim 5.00$ & 3.366 \\
\hline
\end{tabular}

\section{MEASUREMENT SCALES}

Followed by Zhou et al (2017) [4], this paper mainly refers to the research of Baker and Nelson (2005) [5], Senyard et al (2009) [6] to design the questionnaire of entrepreneurial resources bricolage ability with three dimensions including bricolage ability with resources making do, bricolage ability with resources at hand and bricolage ability with resources recombination for new purposes. Among them, bricolage ability with resources making do, bricolage ability with resources at hand will be composed of 3 question indicators respectively, and bricolage ability with resources recombination for new

Table 2. Current situation of entrepreneurial resource bricolage ability of financial college students

\begin{tabular}{|c|c|c|c|}
\hline \multirow{2}{*}{$\begin{array}{c}\text { Variables/Dimensions } \\
\text { entrepreneurial } \\
\text { resource bricolage } \\
\text { ability }\end{array}$} & bricolage with resources making do & 3.65 & Mean Value \\
\cline { 2 - 4 } & bricolage with resources at hand & 3.51 & Above benchmark \\
\cline { 2 - 4 } & $\begin{array}{c}\text { bricolage with resources recombination } \\
\text { for new purposes }\end{array}$ & 3.46 & Above benchmark \\
\cline { 2 - 4 } & entrepreneurial resource bricolage ability & 3.53 & Above benchmark \\
\hline
\end{tabular}

The results of confirmatory factor analysis through AMOS17.0 showed in Table 1: $\mathrm{CFI}=0.947$, GFI $=0.933$, $\mathrm{RMR}=0.033, \quad \mathrm{RMSEA}=0.086$ and $\chi 2 / \mathrm{df}=107.703 / 32$ $=3.366$. It can be seen that the entrepreneurial resources bricolage ability scale has good validity. Therefore, the data from the entrepreneurial resources Bricolage ability scale can be used for further data analysis.

\section{DATA ANALYSIS}

This article takes 318 undergraduates and postgraduates from a financial application-oriented university as the research object to investigate and study the status quo of entrepreneurial resources bricolage ability. The results of the study show:

Firstly, the entrepreneurial resource bricolage ability of financial college students is generally positive (see Table 2), with an overall average of 3.53 which above the 3.0 benchmark. Among them, the average value of bricolage with resources making do is the highest which purposes will be composed of 4 question indicators. According to Zhou et al (2016) [4] and other practices, reliability and validity test with SPSS19.0 were done. Reliability tested results show that Cronbach's $\alpha$ coefficient of bricolage ability with resources making do, bricolage ability with resources at hand and bricolage ability with resources recombination for new purposes are $0.831,0.811$ and 0.822 respectively, which are all greater than the minimum requirement of 0.7 with the Item-Total Correlation of all items are greater than 0.3 . It shows that the entrepreneurial resources bricolage ability scale has good reliability.

equal to 3.65 , the average value of bricolage with resources at hand is the second which equal to 3.51 , and the average value of bricolage with resources recombination for new purposes is the lowest which equal to 3.46 , are all higher than the 3.0 benchmark. It shows that, financial college students have good entrepreneurial resource bricolage ability, which can help students achieve better entrepreneurial performance in future entrepreneurship in the society. As strong entrepreneurial resource bricolage ability is an important ability for financial college students to succeed in their future entrepreneurship, which can help entrepreneurial teams plan and create good entrepreneurial services/products, financial college students' bricolage with resources at hand and bricolage with resources recombination for new purposes still need to continue to improve, especially the enhancement of bricolage with resources recombination for new purposes, which will promote the promotion of 
entrepreneurial services/products.. Therefore, college educators should continue to strengthen the cultivation of students' bricolage with resources recombination for new purposes.

Secondly, financial college students of different genders have significant differences in the overall cultivation of entrepreneurial resource bricolage ability. At the same time, there are significant differences in bricolage with resources recombination for new purposes. The results of statistical analysis of variance show in Table 3 that the $F$ value of the difference in overall entrepreneurial resource bricolage ability is 4.356, and $\mathrm{P}=0.038<0.05$ reaches a significant level, indicating that males will have better overall entrepreneurial resource bricolage ability; the difference $\mathrm{F}$ value of each sub-ability were $1.847(\mathrm{P}=0.175>0.05)$, $2.462(\mathrm{P}=0.118>0.05)$ and $4.388(\mathrm{P}=0.037<0.05)$, which show that only bricolage with resources recombination for new purposes reached a significant level. That is to say, specific to different sub-dimension abilities, it can be found that male students will have better bricolage with resources recombination for new purposes than female students. Male students and female students will have no difference in bricolage with resources making do and bricolage with resources at hand. Therefore, in entrepreneurship education and training, differentiated and intensive training designs should be made for students of different genders. For example, male students should be given more training opportunities to complete tasks with resources when they lack resources, and female college students should be provided with more training opportunities on logical or creative areas, and develop more targeted modular theory courses and training courses with corresponding teaching methods.

Table 3. Variance analysis of entrepreneurial resource bricolage ability among students of different genders

\begin{tabular}{|c|c|c|c|c|}
\hline Variables & $\begin{array}{c}\text { entrepreneurial resource } \\
\text { bricolage ability }\end{array}$ & $\begin{array}{c}\text { bricolage with } \\
\text { resources making do }\end{array}$ & $\begin{array}{c}\text { bricolage with } \\
\text { resources at hand }\end{array}$ & $\begin{array}{c}\text { bricolage with resources } \\
\text { recombination for new } \\
\text { purposes }\end{array}$ \\
\hline Male & 3.618 & 3.714 & 3.597 & 3.561 \\
\hline Female & 3.483 & 3.607 & 3.464 & 3.405 \\
\hline F value & 4.356 & 1.847 & 2.462 & 4.388 \\
\hline P value & 0.038 & 0.175 & 0.118 & 0.037 \\
\hline
\end{tabular}

Table 4. Variance analysis of different educational levels on entrepreneurial resource bricolage ability

\begin{tabular}{|c|c|c|c|c|}
\hline Variables & $\begin{array}{c}\text { entrepreneurial resource } \\
\text { bricolage ability }\end{array}$ & $\begin{array}{c}\text { bricolage with } \\
\text { resources making do }\end{array}$ & $\begin{array}{c}\text { bricolage with } \\
\text { resources at hand }\end{array}$ & $\begin{array}{c}\text { bricolage with resources } \\
\text { recombination for new } \\
\text { purposes }\end{array}$ \\
\hline Undergraduate & 3.461 & 3.743 & 3.417 & 3.283 \\
\hline Graduate & 3.615 & 3.537 & 3.622 & 3.668 \\
\hline F value & 6.085 & 7.359 & 6.365 & 30.722 \\
\hline P value & 0.014 & 0.007 & 0.012 & 0.000 \\
\hline
\end{tabular}

Thirdly, there are significant differences in the cultivation of the overall entrepreneurial resource bricolage ability among students of different educational levels, and significant differences in all major abilities. The results of the statistical analysis of variance showed in table 4 that the overall difference in entrepreneurial resource bricolage ability $\mathrm{F}$ value was $6.085, \mathrm{P}=0.014$ $<0.05$ reached a significant level, indicating that graduate students have a higher entrepreneurial resource bricolage ability (mean value is 3.615), while the average entrepreneurial resource bricolage ability of undergraduate students was 3.461. In addition, while the entrepreneurial resource bricolage ability of undergraduates and postgraduates in current finance and economics colleges and universities is significantly different in general, there are also significant differences in the specific sub-dimension abilities. The statistical data found that graduate students are good at bricolage with resources recombination for new purposes and bricolage with resources at hand, while undergraduates are good at bricolage with resources making do.
Therefore, in the education and training of entrepreneurship education, an entrepreneurial education level curriculum with gradient characteristics should be developed for students at the educational level.

\section{SUGGESTIONS FOR THE REFORM OF TALENT TRAINING MODE}

Based on the research conclusions obtained from data analysis, in order to strengthen the cultivation and improvement of the entrepreneurial resource bricolage ability of financial college students, this research puts forward the corresponding talent training reform suggestions as follows:

Firstly, increase the content of existing courses. Through literature review, this study found that bricolage with resources making do, bricolage with resources at hand, and bricolage with resources recombination for new purposes are important dimensions that constitute entrepreneurial resource bricolage ability and play an important role in the 
improvement of entrepreneurial quality. And through investigation, it is found that the students' ability values in these aspects are not particularly high, and they cannot reach the excellent value of 4.0. The current entrepreneurship education courses offered by major colleges and universities mainly focus on company establishment, strategic management, marketing, financial management, operation management and other enterprise management content. Few courses can provide specialized resource acquisition, integration and operation for entrepreneurship. The abilities of students in these aspects are obtained through training when they have to face and solve the plight of scarcity in the process of entrepreneurship in the future, and lack the theoretical integrity. Therefore, it is recommended to expand the content of entrepreneurship education courses and provide additional courses such as "Entrepreneurship Resource Acquisition", "Entrepreneurship Resource Integration", and "Innovative Application". Moreover, for the different levels of undergraduate and postgraduate education, different levels of middle and high-level courses should be developed to learn in a gradual and orderly manner.

Secondly, reform the existing teaching methods. Traditional classroom knowledge imparting teaching mode tends to make students fall into a tired learning trap, which will gradually obliterate students' entrepreneurial enthusiasm and knowledge absorption initiative. In addition, as a very practical business activity, entrepreneurship pays great attention to practice; and entrepreneurship usually faces the dilemma of lack of resources. Therefore, schools should cooperate with more commercial institutions or entrepreneurial incubators to build entrepreneurial practice bases and enrich entrepreneurial classroom teaching methods so that students can learn by doing to promote themselves. Let students learn to learn and use the resources bricolage ability in the face of resource scarcity, break through the resource dilemma, so as to achieve the success of entrepreneurship.

Thirdly, build a team of off-campus tutors with entrepreneurial practice. To fundamentally improve the entrepreneurial quality of students, and still be able to start entrepreneurial projects and succeed even in the face of lack of resources, excellent instructors with rich experience are indispensable. It is recommended that while cooperating with commercial institutions or entrepreneurial incubators to build an entrepreneurial practice base, it is recommended that the corresponding tutors should be invited to the school to teach course experience to cultivate the resources Bricolage ability, and then enhance entrepreneurial literacy.

Finally, although this article has obtained important conclusions from the perspective of entrepreneurial resources bricolage ability in financial colleges and universities for entrepreneurship training reform, in order to make the research conclusions more universal, future research can expand the scope of data collection to provide better reference value.

\section{CONCLUSION}

Data from 318 students at a financial university as sample to investigate the entrepreneurial resources bricolage ability of college students with results found that: Firstly, the entrepreneurial resources bricolage ability of financial college students is generally positive; Secondly, there are significant differences in the overall resources bricolage ability of students in different genders and between graduate students and graduate students. Finally, reform proposals were provided.

\section{ACKNOWLEDGMENTS}

This article is supported by the Guangdong University of Finance and Economics Degree and Postgraduate Education Reform Research Project (No. 2021YB16) and the Guangdong University of Finance and Economics Undergraduate Teaching Quality and Teaching Reform Project with title "Research on the Evaluation Index System and Training Path of the Entrepreneurship Quality of Applied Finance College Students" (No. 59).

\section{REFERENCES}

[1] Shepherd D, Douglas E, Shanley M. New Venture Survival: Ignorance, External Shock, and Risk Reduction Strategies [J]. Journal of Business Venturing, 2000,15:393-410.

[2] Zhou J M, Zhang X S, Zhou Y W. Impact of resource bricolage and $R \& D$ team's impromptu creation on the new product development performance of startups [J]. Science Research Management, 2019, 40(1):54-62.

[3] Zhou J M, Chen L J. A Study of Cooperative Innovation Ability and Bricolage Ability on College Students' Entrepreneurial Qualities[J]. Advances in Business and Finance, 2016, 4: 51-56.

[4] Zhou J M. Entrepreneurial Spirit, Entrepreneurial Bricolage and New Product Development Capabilities [J]. Lecture Notes in Management Science, 2017, 25: 21-26.

[5] Baker T, Nelson R E. Creating something from nothing: Resource construction through entrepreneurial bricolage $[\mathrm{J}]$. Administrative science quarterly, 2005, 50(3): 329-366.

[6] Senyard J, Baker T, Davidsson P. Entrepreneurial bricolage: Towards systematic empirical testing [J]. Frontiers of Entrepreneurship Research, 2009, 29(5): 1-14. 